\title{
The method of assessing the quality of the excavation workmanshift in the underground coal mine
}

\author{
Marcin Cholewa ${ }^{1}$, and Stanisław Duży ${ }^{2,1}$ \\ ${ }^{1}$ Polska Grupa Górnicza, Oddział KWK "Ruda”, Ruda Śląska, Poland \\ ${ }^{2}$ Silesian University of Technology, Faculty of Mining and Geology, Gliwice, Poland
}

\begin{abstract}
A new method of assessing the quality of the heading workmanship was proposed in this article. The method includes 13 parameters characterizing the quality of excavation performance, namely: the heading breach width, the heading useful height, the heading useful width, the angle of inclination of arch, the horizontal offset of arch (direction), the vertical offset of arch (cancellation), distance between mine roadway support, the arch set overlap length, the tightening torque of clamps screws, development of struts, dadding and the contact of support with rock strata. For each element of the excavation the number of quality points is determined based on by the amount of multiples of the quality statistics QN from the qualifying constant. After adding up the points, the final grade is obtained in the form of the quality category. The conclusion is an example of the evaluation of the quality of heading workmanship according to the developed method.
\end{abstract}

Keywords: mining engineering, underground structure, build quality

\section{Introduction}

The basic purpose of designing, making and maintaining an excavation is to ensure its stability, which is possible under three basic conditions:

- good design - recognized geological and mining conditions, well-defined properties of the massif, good design methods, flawless calculations,

- exact execution - accurate breakthrough, accurate support (material quality, support quality, assembly accuracy),

- proper maintenance - conducting excavation and support diagnostics and performing necessary maintenance works.

Performance errors are usually the sum of the variability of the conditions under which excavations are made and the inaccuracies of the support elements are made. The variability

${ }^{1}$ stanislaw.duzy@polsl.pl 
of the drilling conditions of the excavation causes that the dimensions of the excavation breakdown along its run are varied, which affects the quality of workmanship and the conditions of cooperation between the support and the rock mass [1,2].

The reliability of the support and the safety of the mine workings in the mine to a large extent, the quality of its implementation. The design of the excavation assumes accurate, design dimensions and standard parameters regarding the bearing capacity of the support, and possible executive and material inaccuracies are taken into account by assuming appropriate safety factors $[1,2]$. In this situation, there is a need to develop a uniform method for assessing the quality of excavation performance, allowing for control of the compliance of the project with consideration of tolerances.

\section{Assessment of the quality of the heading workmanship}

The assessment of the quality of the heading was based on the quality requirements according to the "PN-ISO 3951: 1997" standard. Random sampling of non-compliant units based on a numerical evaluation of properties; procedures and nomograms [3] and the point method [4].

The proposed model for the quality evaluation of a heading does not treat units of poor support performance as a whole, as was the case in the standard [5], but focuses on the assessment of its individual features separately. The final rating gives us not only information on the number of non-compatible openings in the excavation, but most importantly, which features of the excavation are not in accordance with the standard and indicates the amount of deviation of the quality of workmanship from the intended one. This gives us clear and transparent information about mistakes made while mining, their importance and the possibility of repairing them.

The number of supports required to assess the quality of excavation performance and the value of the acceptable limit of AQL quality were determined according to the "PN-ISO 3951: 1997" standard.

As the value of the acceptable limit of AQL quality in accordance with the above a standard is understood as a level of quality that corresponds to the worst tolerable average level of process quality.

In the method of assessing the quality of workings examined in the work, the value AQL $=10 \%$ was assumed, which means that $10 \%$ of units not complying with the requirements of the norm in a given element of the excavation are allowed. Each element that meets these requirements obtains 10 quality points.

The value of the AQL qualifying constant depends on:

- the purpose of the excavation in the mine's production process,

- the planned lifetime of the excavation.

The recommended form of testing the quality of the excavation of the excavation is such that the controls are carried out on a regular basis during drilling. For this purpose, it is necessary to know the expected length of the designed excavation in order to determine the total number of frames to be tested and to determine the distance between the arches to be tested. With this data one should check the quality of the first made risers in the excavation, and then examine the next arch at distances equal to one another according to the pattern given in Table 1. To obtain the desired distance between the tested arches, divide the total number of risers in the excavation by the number of archs required for testing. For example, for an excavation with a length of $1000 \mathrm{~m}$, check the quality of the 35 risers at a distance of 28 arches. 
Table 1. One-stage test plan used during normal control according to "PN-ISO 3951: 1997 [3]

\begin{tabular}{|c|c|c|c|}
\hline $\begin{array}{c}\text { The total number of } \\
\text { supports in the } \\
\text { excavation }\end{array}$ & $\begin{array}{c}\text { Number of the arch } \\
\text { required for testing }\end{array}$ & $\begin{array}{c}\text { The value of the } \\
\text { qualifying constant } \\
\text { for } \mathbf{A Q L}=\mathbf{6 . 5 \%}\end{array}$ & $\begin{array}{c}\text { The value of the } \\
\text { qualifying constant } \\
\text { for } \mathbf{A Q L}=\mathbf{1 0 \%}\end{array}$ \\
\hline 9 to 15 & 3 & 0,765 & 0,566 \\
\hline 16 to 25 & 4 & 0,814 & 0,617 \\
\hline 26 to 50 & 5 & 0,874 & 0,675 \\
\hline 51 to 90 & 7 & 0,955 & 0,755 \\
\hline 91 to 150 & 15 & 1,03 & 0,828 \\
\hline 151 to 280 & 20 & 1,09 & 0,886 \\
\hline 281 to 400 & 25 & 1,12 & 0,917 \\
\hline 401 to 500 & 35 & 1,14 & 0,936 \\
\hline 501 to 1200 & 50 & 1,18 & 0,969 \\
\hline 1201 to 3200 & 75 & 1,21 & 1,00 \\
\hline 3201 to 10000 & & 1,24 & 1,03 \\
\hline
\end{tabular}

Each case should be examined in all cases, ie:

1. the heading breach height,

2. the heading breach width,

3. the heading useful height,

4. the heading breach width,

5. the angle of inclination of arch,

6. the horizontal offset of arch (direction),

7. the vertical offset of arch (cancellation),

8. distance between mine roadway support,

9. the arch set overlap length,

10. the tightening torque of clamps screws,

11. development of struts,

12. dadding,

13. the contact of support with rock strata.

The frequency of inspection depends on the progress of the excavation drilling.

Research conducted during the excavation of the excavation allows for ongoing control and possible correction of excavation performance. The data collected and developed at the end of the excavation of the excavation allow for the final evaluation of the entire excavation performed separately in respect of each feature.

For quality assessment according to standard [6], the following values are defined for each mining characteristic:

- average value,

where:

$$
\bar{x}=\frac{\sum_{i=1}^{n} x_{i}}{n}
$$

$n$ - the number of support elements tested,

$x_{i}$ - further values of the feature of the tested support element,

- standard deviation:

$$
s=\sqrt{\frac{1}{n-1} \sum_{i=1}^{n}\left(x_{i}-\bar{x}\right)^{2}}
$$


where:

$n$ - the number of support elements tested,

$x_{i}$ - further values of the feature of the tested support element,

- upper tolerance limit $T_{U}$ - value, which determines the upper acceptable limit of compliance for a single feature of the support,

- lower tolerance limit $T_{L}$-a value that determines the lower acceptable limit of compliance for a single support feature,

- upper quality statistics - function of the upper limit of tolerance, average value of the tested support feature and standard deviation:

$$
Q_{U}=\frac{T_{U}-\bar{x}}{s}
$$

- lower quality statistics - function of the lower tolerance limit, average value of the tested support feature and standard deviation:

$$
Q_{L}=\frac{\bar{x}-T_{U}}{s}
$$

Incompatibility is the failure to meet the requirements set by the support. Noncompliances are classified according to the degree of their validity, i.e. class A as having the most significant meaning, class B for non-compliances of lower significance, etc. In the aforementioned studies for class A, an $A Q L$ value of $6.5 \%$ was adopted, whereas for class $\mathrm{B}$ the $A Q L$ value was $10 \%$.

The acceptable level of $A Q L$ quality is the level that in the random control is the limit value of a satisfactory average percentage of non-compliant units in the process.

The qualifying constant is a constant that depends on a certain value of an acceptable level of $A Q L$ quality and the number of tested supports.

For the researched workings, the incompatibility class B was assumed, for which the value of the acceptable limit of $A Q L$ quality is $10 \%$, and the value of the qualifying constant $\mathrm{k}=0.917$ (table 1).

Interpretation of the results of control tests is aimed at reading the scale of executive errors made and finding the reasons for their occurrence.

The next stage of the research is the use of the point method, where the number of quality points is calculated for each element of the excavation. After adding the points, the final assessment of the quality of the excavation and the conditions for its putting into use are obtained. If approval of the excavation is not accepted, a decision should be made about any corrective actions.

The number of quality points is dependent on the multiplicity of $Q_{N}$ quality statistics exceeding the condition $Q_{U}>k$ and $Q_{L}>k$ from the qualifying constant $k$ according to the formula:

where:

$$
x=\frac{k-Q_{N}}{k}
$$

$x$ - the number of times the quality statistics $Q$ exceeds the qualifying constant $k$,

$Q_{N}$ - quality statistics not meeting the condition $Q_{U}>k$ and $Q_{L}>k$,

$k-$ the qualifying constant.

Depending on the size of this multiplicity, which proves the amount of deviation of the quality of a given feature from the requirements set out at the beginning of the study, a given number of points is awarded (Table 2). 
Table 2. Criteria for assessing the quality of excavation performance according to the point method

\begin{tabular}{|c|c|}
\hline $\begin{array}{c}\text { The multiplicity of exceeding the } \boldsymbol{Q}_{\boldsymbol{N}} \\
\text { quality statistics from the qualifying } \\
\text { constant } \boldsymbol{k}\end{array}$ & Number of points \\
\hline to 0,5 - times & 9 \\
\hline from 0,5 to 1,0 - times & 7 \\
\hline from 1,0 to 1,5 - times & 5 \\
\hline from 1,5 to 2,0 - times & 3 \\
\hline from 2,0 to $2,5-$ times & 2 \\
\hline from 2,5 to $3,0-$ times & 1 \\
\hline more than $3,0-$ times & 0 \\
\hline
\end{tabular}

The total number of points of all features gives a comprehensive assessment of the quality of the excavation performance along with the conditions for the approval of the excavation for use. Table 3 presents the criteria for assessing the quality of excavation performance, where 13 elements are tested, and the maximum number of possible points is 130 .

Table 3. Criteria for assessing the quality of excavation performance according to the point method

\begin{tabular}{|c|c|c|l|}
\hline $\begin{array}{c}\text { The total number of points } \\
\text { for the test }\end{array}$ & $\begin{array}{c}\text { Quality } \\
\text { category }\end{array}$ & Specification \\
\hline 13 features & $\mathbf{1 2}$ features & I & $\begin{array}{l}\text { an excavation with reference quality that meets all quality } \\
\text { requirements; }\end{array}$ \\
\hline 120 & 120 & II & $\begin{array}{l}\text { an excavation of very good quality, having slight } \\
\text { deviations from the reference quality, not requiring any } \\
\text { corrections before putting it into service; }\end{array}$ \\
\hline $100-119$ & $90-109$ & III & $\begin{array}{l}\text { an excavation of good quality, which may be approved for } \\
\text { use, with the acceptance of the execution of elements of } \\
\text { the excavation deviating from the required, after its } \\
\text { intended use and planned duration or before being } \\
\text { accepted for use, requiring some corrections of the } \\
\text { elements of the lowest quality, which are very important } \\
\text { in given conditions; }\end{array}$ \\
\hline $80-99$ & $70-89$ & IV & $\begin{array}{l}\text { an excavation of acceptable quality, requiring certain } \\
\text { adjustments to be made prior to being allowed to use of } \\
\text { the lowest quality, and of great importance in given } \\
\text { conditions; requiring increased control of its behavior } \\
\text { during use. }\end{array}$ \\
\hline $70-79$ & $60-69$ & V & $\begin{array}{l}\text { an excavation of poor quality, requiring repair to qualify } \\
\text { for at least category III with possible admissible } \\
\text { shortcomings for given conditions; }\end{array}$ \\
\hline Less than 70 & Less than 60 & VI & $\begin{array}{l}\text { an excavation of very poor quality, unfit for use, requiring } \\
\text { thorough repair to qualify for at least category III with } \\
\text { possible admissible shortcomings for given conditions; }\end{array}$ \\
\hline
\end{tabular}

Assessment criteria for workings where fewer elements have been examined are analogous, ie for workings with 12 elements tested maximum number of points is 120 , and the rating categories are automatically lower by 10 points. The research presented in this 
article presents a control of 12 elements in coal excavations and 13 in stone excavations, in which the leveling of the excavation was additionally examined.

The test results according to the new model of the quality assessment of a heading drill show a specific, numerical range of errors committed in the excavation process and a comprehensive assessment taking into account the conditions of its exploitation.

If it is necessary to repair incorrectly made parts of the excavation and after removing any irregularities committed during the excavation, the next inspection should be carried out in the same way, the test should be started by shifting one more support hatch to increase the effectiveness of the inspection.

\section{Example of evaluation of the $4 \mathrm{~W}$ pavement performance quality}

The 4W heading was drilled in the 504 seam at 920 - $1010 \mathrm{~m}$ depth. The drilling took place using mechanical rock excavation using the AM-50 harvester. The width of the excavation in the light of the support was $5.0 \mathrm{~m}$ and the height $3.5 \mathrm{~m}$. The support was made of flexible steel arch support. In the ancestors of the above-mentioned workings, tests of the quality of their drilling were carried out. The tests included measurements of 12 sizes, namely: the heading breach width, the heading breach height, the heading useful width, the heading useful height, the angle of inclination of arch, the horizontal offset of arch (direction), the vertical offset of arch (cancellation), distance between mine roadway support, the arch set overlap length, the tightening torque of clamps screws and development of struts and dadding.

For example, the selected measurement results are shown in Figures 1-12, and the results of the evaluation of the quality of the excavation performance in Table 4.

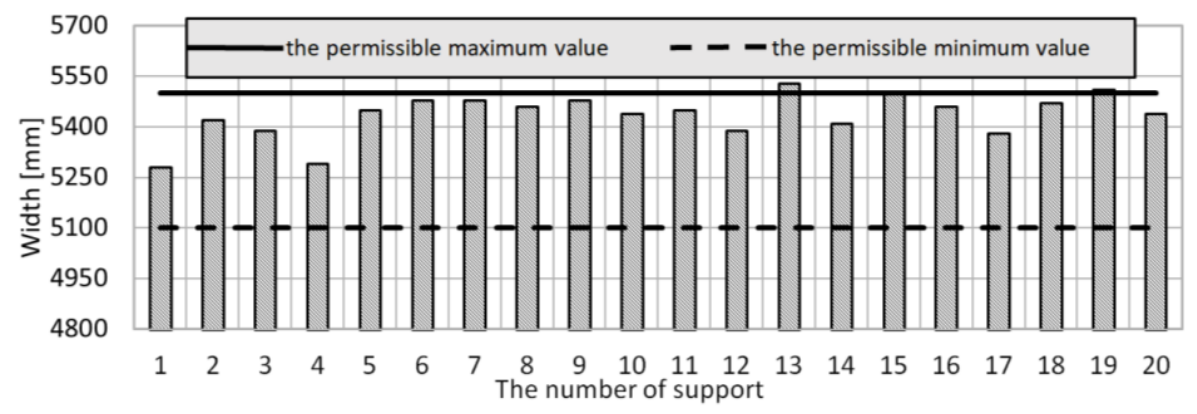

Fig. 1. Results of measurements of the $4 \mathrm{~W}$ heading breach width

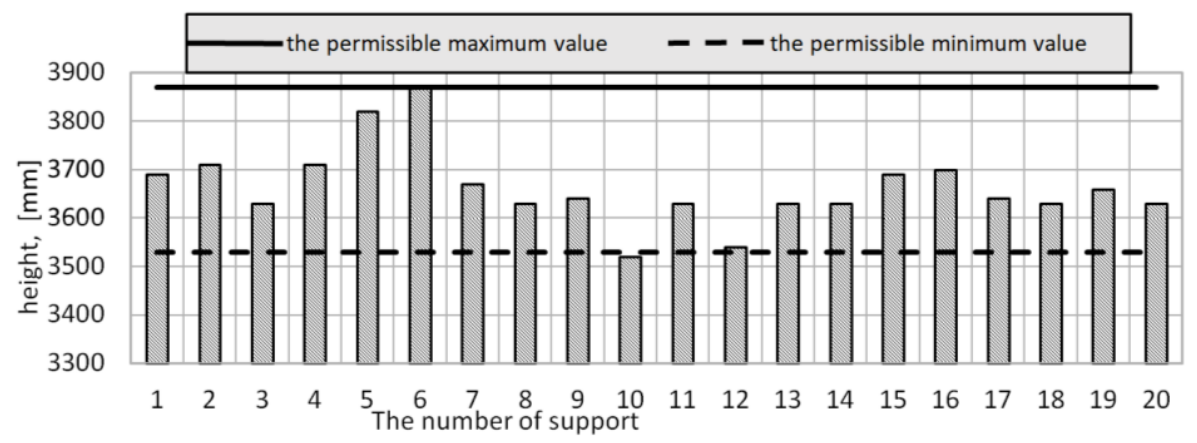

Fig. 2. Results of measurements of the $4 \mathrm{~W}$ heading breach height 


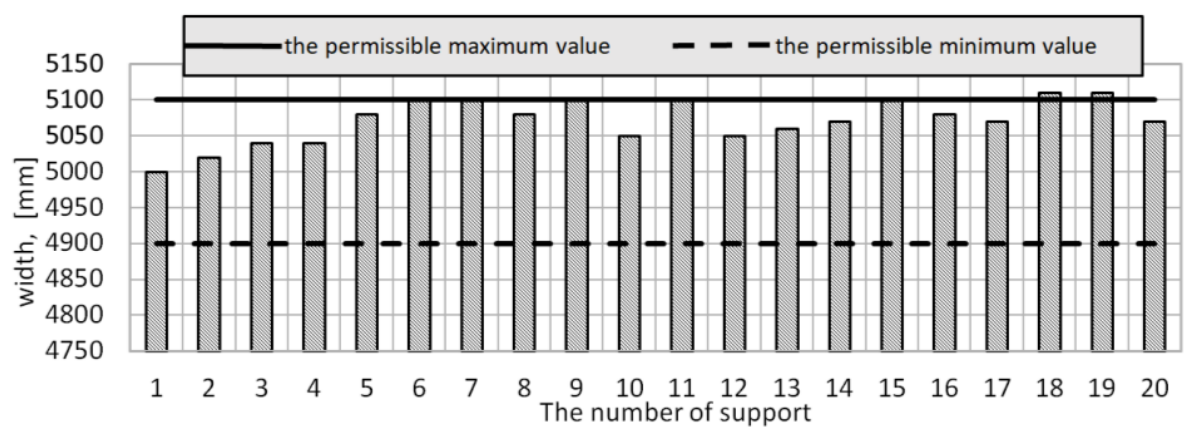

Fig. 3. Results of measurements of the $4 \mathrm{~W}$ heading useful width

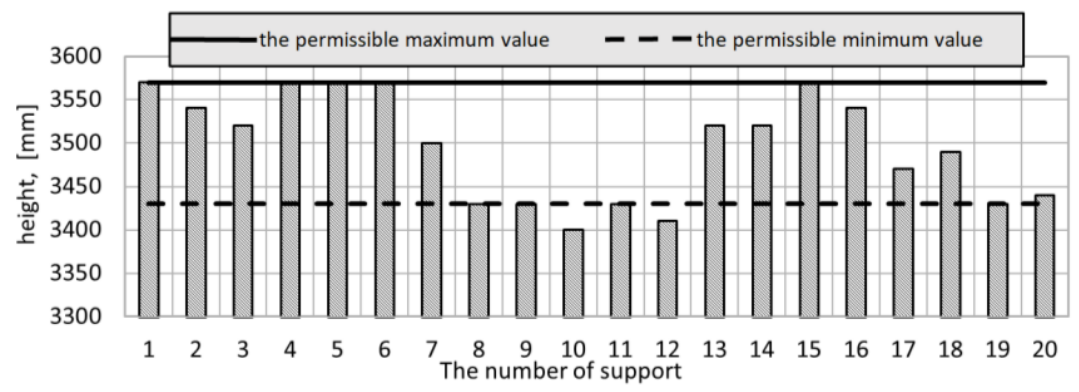

Fig. 4. Results of measurements of the $4 \mathrm{~W}$ heading useful height

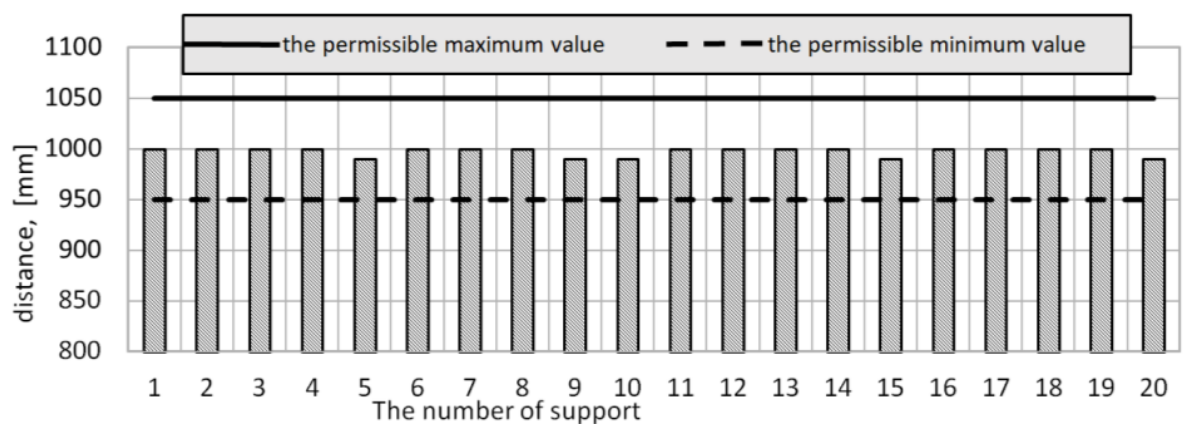

Fig. 5. Results of measuring the distance between mine $4 \mathrm{~W}$ heading support

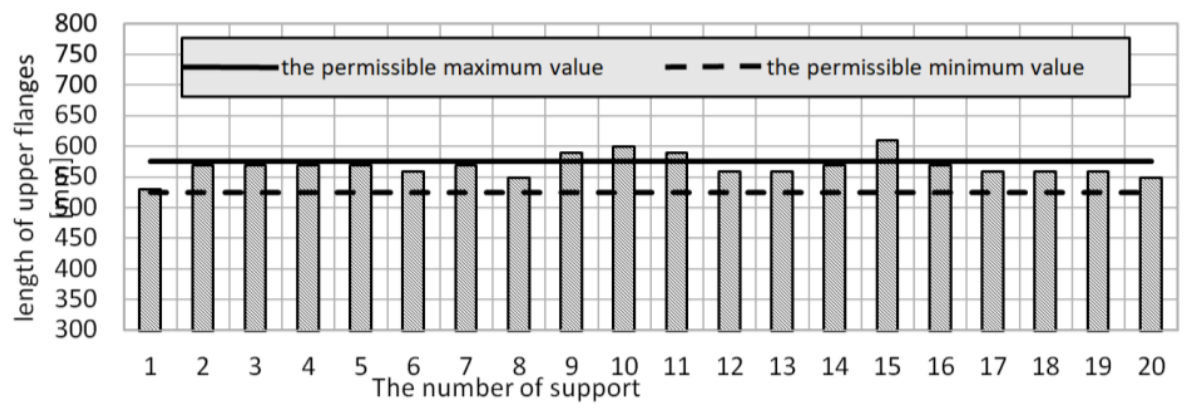

Fig. 6. Results of measurements of the upper the arch set overlap length 


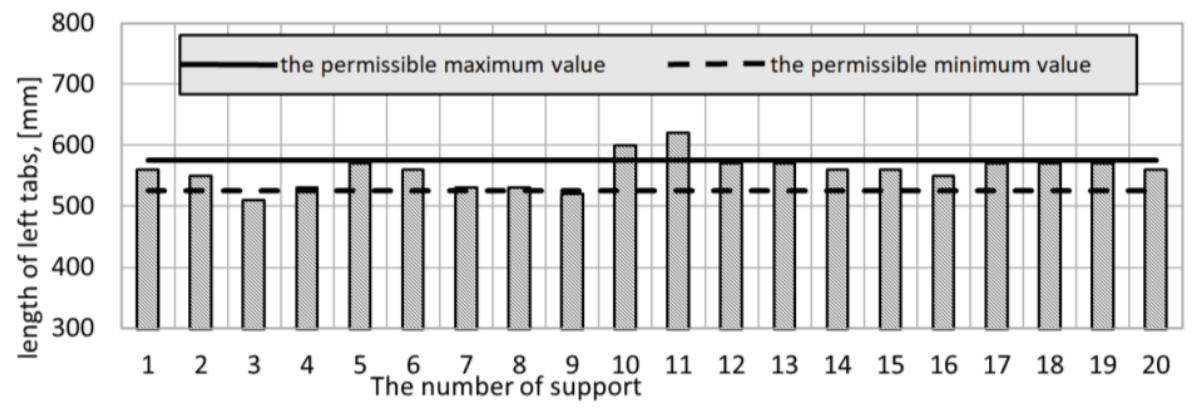

Fig. 7. Results of measurements of the left the arch set overlap length

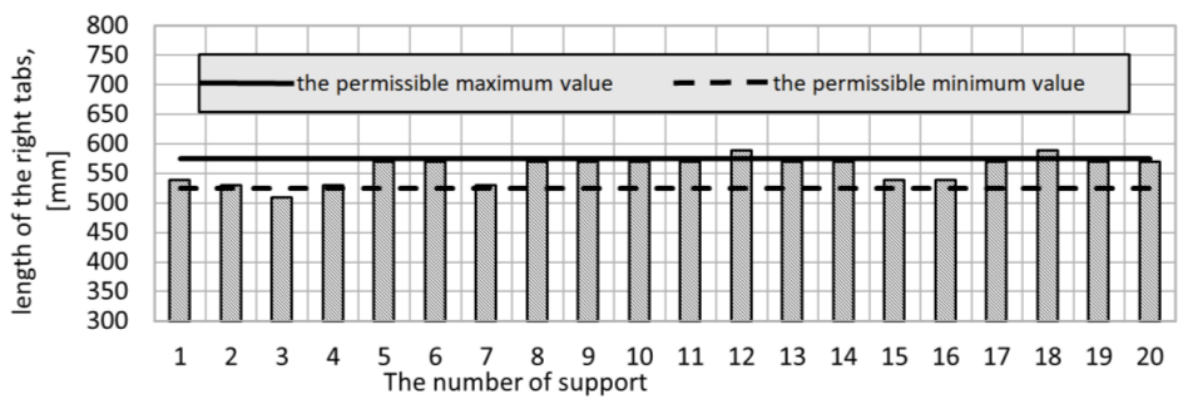

Fig. 8. Results of the measurements of the right the arch set overlap length

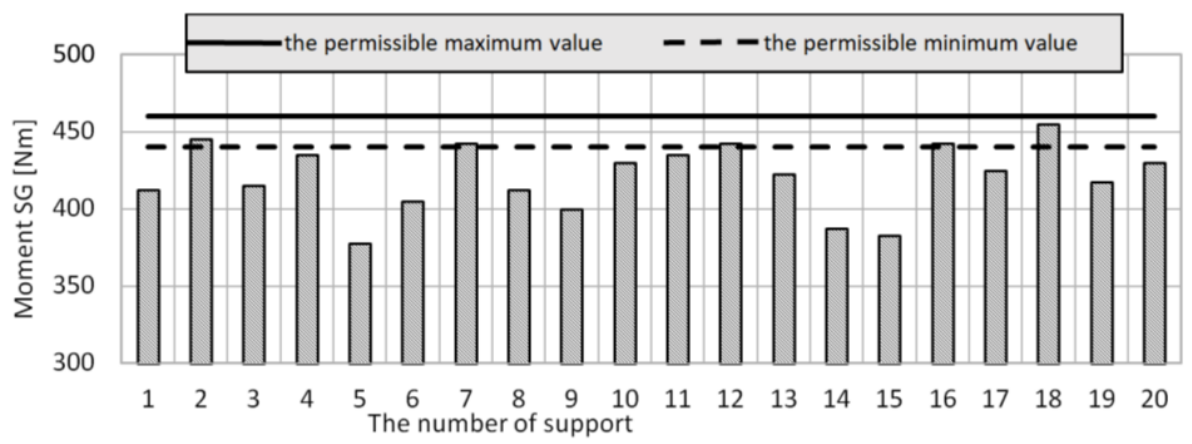

Fig. 9. The results of the tightening torque of upper clamps screws

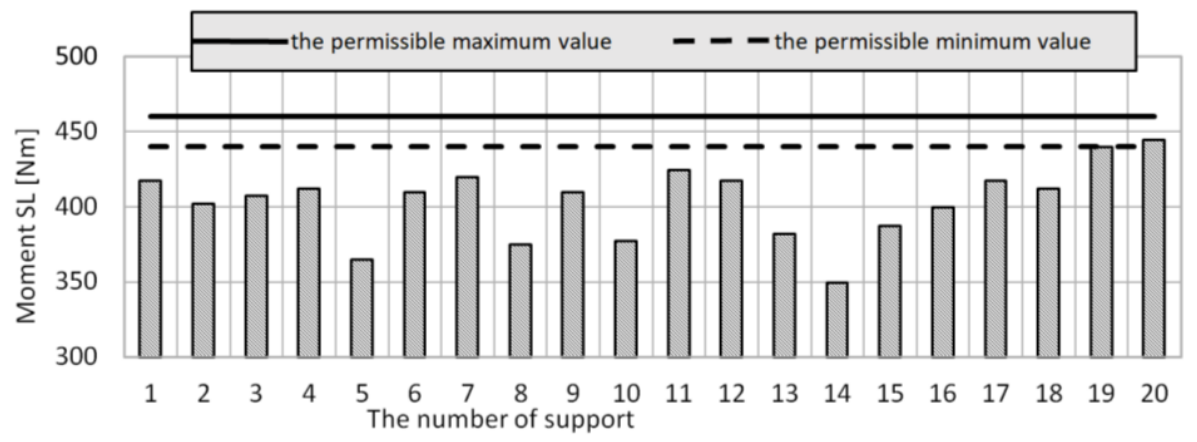

Fig. 10. The results of the tightening torque of left clamps screws 


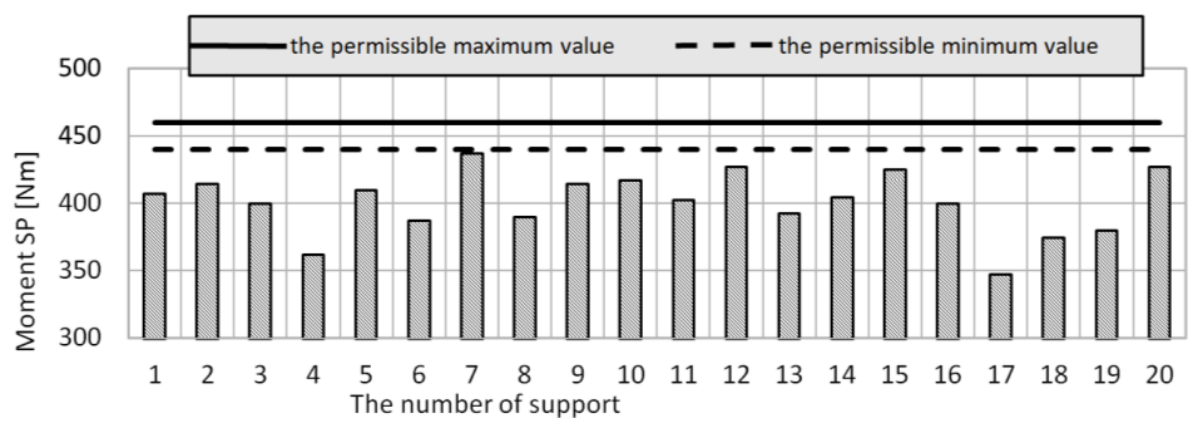

Fig. 11. The results of the tightening torque of right clamps screws

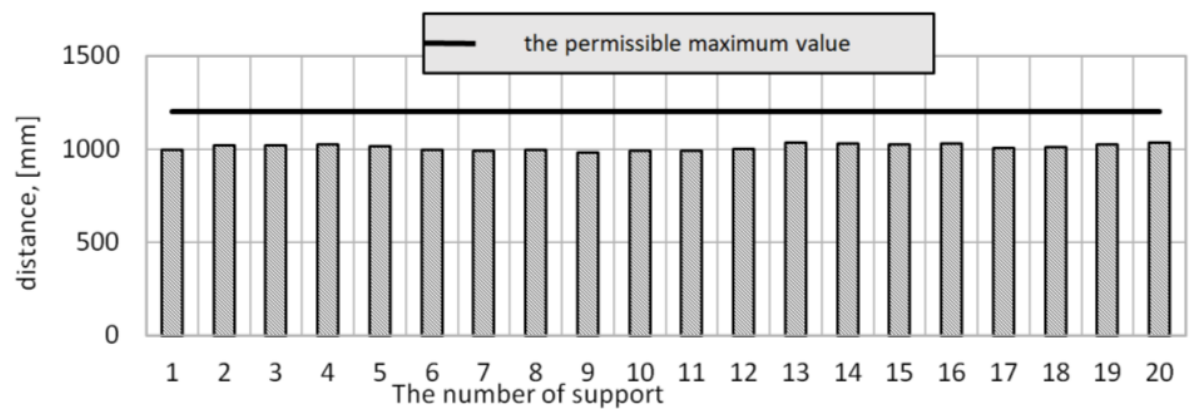

Fig. 12. Results of the measurements of the development of struts

The 4W pavement, according to the developed quality assessment method, obtained 109 points out of 120 possible and was classified to the second category of excavation quality an excavation of good quality that could be approved for use, with acceptance of the elements of the excavation deviating from the required, after its intended use and planned time of use or before being accepted for use requiring some adjustments to the elements of the lowest quality, which are very important in given conditions.

The pavement was designed as a ventilation pit in a place affected by exploitation and its duration was planned for less than 1 year. The lowest point was the quality of the implementation of the opinion and this is the only element requiring correction due to the planned movement of the crew in this excavation. Due to the low defectiveness, the scope of repair of this element is very small. 
Table 4. Evaluation of the performance quality of the $4 \mathrm{~W}$ heading

\begin{tabular}{|c|c|c|c|c|c|c|c|c|c|c|c|}
\hline $4 \mathrm{~W}$ excavation & 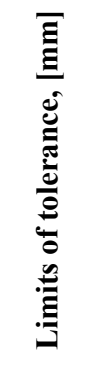 & 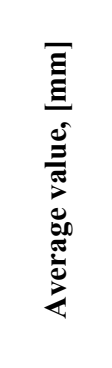 & 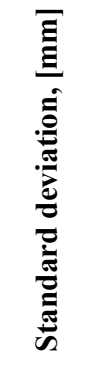 & 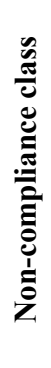 & 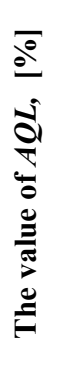 & 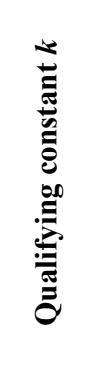 & 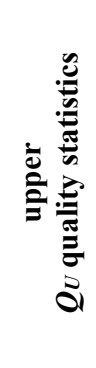 & 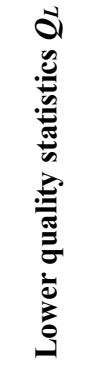 & 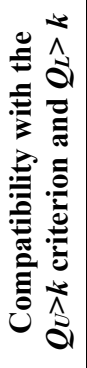 & 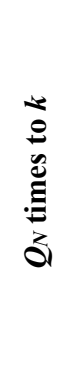 & 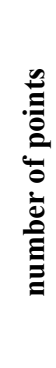 \\
\hline $\begin{array}{l}\text { The heading } \\
\text { breach height }\end{array}$ & $\begin{array}{l}3870 \\
3530\end{array}$ & 3663,5 & 79,16 & B & 10 & 0,917 & 2,61 & 1,69 & YES & & 10 \\
\hline $\begin{array}{l}\text { The heading } \\
\text { breach width }\end{array}$ & $\begin{array}{l}5700 \\
5000\end{array}$ & 5435,5 & 62,25 & B & 10 & 0,917 & 4,25 & 7 & YES & & 10 \\
\hline $\begin{array}{l}\text { The heading } \\
\text { useful height }\end{array}$ & $\begin{array}{l}3570 \\
3430\end{array}$ & 3496 & 61,08 & B & 10 & 0,917 & 1,21 & 1,08 & YES & & 10 \\
\hline $\begin{array}{l}\text { The heading } \\
\text { useful width }\end{array}$ & $\begin{array}{l}5100 \\
4900\end{array}$ & 5071,5 & 30,83 & B & 10 & 0,917 & 0,92 & 5,56 & YES & & 10 \\
\hline $\begin{array}{l}\text { The angle of } \\
\text { inclination of } \\
\text { arch }\end{array}$ & $\begin{array}{c}6 \\
-6\end{array}$ & 1,2 & 2,46 & B & 10 & 0,917 & 1,95 & 2,93 & YES & & 10 \\
\hline $\begin{array}{l}\text { The horizontal } \\
\text { offset of arch }\end{array}$ & $\begin{array}{c}100 \\
-100\end{array}$ & 22 & 75,51 & B & 10 & 0,917 & 1,03 & 1,62 & YES & & 10 \\
\hline $\begin{array}{l}\text { The vertical } \\
\text { offset of arch }\end{array}$ & & & & B & 10 & 0,917 & & & & & \\
\hline $\begin{array}{l}\text { Distance between } \\
\text { mine roadway } \\
\text { support }\end{array}$ & $\begin{array}{c}1050 \\
950\end{array}$ & 997,5 & 4,44 & B & 10 & 0,917 & 11,82 & 10,7 & YES & & 10 \\
\hline $\begin{array}{l}\text { The arch set } \\
\text { overlap length }\end{array}$ & $\begin{array}{l}630 \\
570\end{array}$ & 613,17 & 23,91 & B & 10 & 0,917 & 0,7 & 1,81 & NO & 0,23 & 9 \\
\hline $\begin{array}{l}\text { The tightening } \\
\text { torque of clamps } \\
\text { screws }\end{array}$ & $\begin{array}{l}410 \\
390\end{array}$ & 408,58 & 23 & B & 10 & 0,917 & 0,06 & 0,81 & NO & 0,93 & 7 \\
\hline $\begin{array}{l}\text { Development of } \\
\text { struts }\end{array}$ & 1200 & 912,75 & 78,85 & B & 10 & 0,917 & 3,64 & 11,58 & YES & & 10 \\
\hline Dadding & 0 & 0,3 & 0,47 & B & 10 & 0,917 & $-0,64$ & & NO & 1,7 & 3 \\
\hline $\begin{array}{l}\text { The contact of } \\
\text { support with rock } \\
\text { strata }\end{array}$ & 90 & 89,5 & 9,45 & B & 10 & 0,917 & & 9,47 & YES & & 10 \\
\hline & & & & & & & & & & & 109 \\
\hline
\end{tabular}




\section{Summary}

The impact of the human factor on the accuracy of the excavation of the headings justifies the need and purposefulness of the quality control of the excavation as an important condition for maintaining its stability.

Based on the results of the tests carried out and the analysis of their results, a new method for assessing the quality of the excavation work performance in the underground hard coal mine was proposed. The new tool for controlling and assessing the quality of the excavation proposed in this work should to a large extent order and facilitate this process. The method includes 13 parameters characterizing the quality of excavation performance, namely: the heading breach width, the heading breach height, the heading useful height, the heading useful width, the angle of inclination of arch, the horizontal offset of arch (direction), the vertical offset of arch (cancellation), distance between mine roadway support, the arch set overlap length, the tightening torque of clamps screws, development of struts, dadding and the contact of support with rock strata.

The proposed new way of assessing the quality of heading performance is based on the basis of statistical data analysis. This tool gives a clear picture of the quality of the excavation work with a detailed visualization of the quality of each of its elements separately. The results of such a control allow for a quick response and indicate in a transparent way the scope of the necessary adjustment. The final assessment defines the quality of the excavation and indicates, using specific values, the scale of the shortcomings of those elements of the excavation that do not meet the assumed requirements.

The new method of assessing the quality of excavation workplaces offers simple research plans and uses simple mathematical relationships to determine the quality of excavation performance, thanks to which it is a tool that can be successfully used in practice.

\section{References}

1. Chudek M., Duży S., Głuch P., Kleta H., Cholewa M., Winch M., Stateczność wyrobisk korytarzowych warunkiem efektywnej eksploatacji i bezpieczeństwa pracy $w$ kopalniach podziemnych. Gliwice (2011).

2. Duży S., Studium niezawodności konstrukcji obudowy i stateczności wyrobisk korytarzowych $w$ kopalniach węgla kamiennego $z$ uwzględnieniem niepewności informacji. ZN Politechniki Śląskiej, s. Górnictwo, z.277. Gliwice (2007)

3. Norma polska PN-ISO 3951. Kontrola wyrywkowa procentu jednostek niezgodnych na podstawie liczbowej oceny właściwości; procedury i nomogramy.

4. Cholewa M., Metoda oceny jakości wykonania wyrobiska korytarzowego w podziemnej kopalni węgla kamiennego. Praca doktorska, Politechnika Śląska, Gliwice (2015)

5. Norma polska PN-G-06011:1990, Wyrobiska korytarzowe poziome $i$ pochyte $w$ kopalniach. Wyrobiska obudowane odrzwiami z ksztattowników korytkowych. Wymagania i badania przy odbiorze, (1990)

6. Norma polska PN-ISO 2859-2: 1996. Procedury kontroli wyrywkowej metoda alternatywna. Plany badania na podstawie jakości (LQ) stosowane podczas kontroli partii izolowanych, (1996) 